\title{
Navigating Civil War through Youth Migration, Education, and Family Separation ${ }^{1}$
}

\author{
ADRIAN A. KHAN AND JENNIFER HYNDMAN
}

\section{Abstract}

Why did youth move from their trans-Himalayan villages at very young ages to attend school with the risk of prolonged family separation? An in-depth study of youth from rural trans-Himalayan villages who travelled to Kathmandu, capital of Nepal, to live and study at a (free) boarding school, funded by both national and international donors, provides a starting point to address this question. The "People's War" from 1996 to 2006 in Nepal contextualizes the study, given that the Maoist insurgency in the Himalayan hinterland aimed to recruit youth to the rebel cause. The study of youth from the trans-Himalayan region living at the boarding school as students was conducted between April and July 2014 in Kathmandu. The youth arrived at the school between the ages of four and ten years, and did not see their families for several years after their arrival, given the significant distances between their villages and the associated costs of travel. Drawing on scholarship in children's geographies, the narratives of these youth are employed to underscore their agency in these biographies of migration and better understand these difficult separations during political uncertainty and civil war.

\section{Résumé}

Qu'est-ce qui a motivé certaines jeunes personnes de quitter leurs villages trans-himalayens et de poursuivre leurs études dans le contexte d'une institution scolaire, avec le risque que cela comportait d'être séparé de leurs familles pour une période prolongée, et cela à un âge très précoce? Une étude en profondeur de jeunes personnes provenant de villages trans-himalayens ruraux, qui ont effectué le trajet jusqu'à la capitale Katmandu, afin d'y vivre et de faire leurs études à un pensionnat (gratuit) subventionné par des bénévoles nationaux ainsi qu'internationaux, constitue un point de départ pour aborder cette question. La «Guerre populaire» au Népal, qui a duré de 1996 jusqu'à 2006, fournit un contexte à l'étude, étant donné que l'insurrection maoiste dans l'arrière-pays himalayen avait pour but de recruter les jeunes à la cause des insurgés. Cette étude de jeunes personnes de la région trans-himalayenne, résidant au pensionnat en tant qu'étudiants, a été menée à Katmandu entre avril et juin 2014. Les jeunes, âgés de 4 à 10 ans à la date de leur arrivée à l'école, restaient sans voir leurs familles pendant plusieurs années après leur arrivée, en raison des distances considérables entre leurs villages et l'école, et les frais de voyage qui s'y associaient. En se basant sur les travaux universitaires en géographies des enfants, les récits de ces jeunes servent à mettre l'accent sur leur capacité d'action et d'initiative dans le contexte de ces biographies de migration, et à mieux comprendre la nature de ces séparations difficiles en période d'instabilité politique et de guerre civile.

\section{Introduction}

It was so peaceful lying in the fields for hours and stare at the hills and trees around me while the goats ate. Things changed a lot once the Maoists came. My parents were in constant fear that they would take me, so they sent me to Kathmandu to study and be safe.

—Wangdak, age seventeen, Lower Mustang²

7 his article explores the antecedents of migration, education, and family separation in the context of civil war in Nepal from 1996 to 2006 and beyond. Maoist insurgents promised positive political and economic change 
to many rural Himalayan families during the "People's War," 3 but also aimed to recruit their children into the rebel movement to fight for this change. ${ }^{4}$ While relative poverty was also a reality for many of the households that sent children to Kathmandu, it was not the sole driver of the ruralurban migration to the capital city. Decisions to migrate were made within rural political environments ${ }^{5}$ that relied on Maoist indoctrination in educational settings. ${ }^{6}$ Protection from recruitment was a factor, but scarce economic and educational opportunities for youth also prevailed. ${ }^{7}$

The article documents stories told by relocated youth, and in so doing, extends children-centred scholarship, complementing rich and extensive research on youth in relation to the war, poverty, and distorted development of the rural trans-Himalayan hinterland, far from the Kathmandu Valley and capital city. We avoid the term displacement in this article, despite our analysis of migration as related to war, precisely because it seldom accounts for the highly intentional acts taken by families in the trans-Himalayan region to relocate one or more family members, albeit in restricted contexts of warfare and abduction.

After outlining the terminology and methodology for the article, the second section briefly reviews the extensive scholarship on conditions in the trans-Himalayan region that shaped decisions for people living there, including the conditions of civil war from 1996 to 2006, and beyond. The article also engages with the children's geographies literature and scholarship about youth in contexts of forced migration to foreground the narratives of youth interviewed for the study. Our aim is to provide a more "youth-full" account of the initial migration to Kathmandu and return to their villages after years of absence. By capturing the voices and knowledge of youth who moved to the capital, ostensibly for education, a more nuanced and inclusive knowledge can be generated. ${ }^{8}$ The body of scholarship foregrounding youth experiences and accounts of conflict, displacement, and refugee studies is relatively small, though more scholars are taking up this task. 9

The choice of concepts is methodologically significant. We choose to use "youth" in the study, which is not a homogenized category, but one that is conceptualized and constructed differently across time, space, and societies, across the disparities of Global South and Global North, and within a country, like Nepal. To elaborate, "teenager" was a category created in the West in the 1950s, and later imported into Nepal through globalizing forces such as the spread of magazines and media. Some adults in Nepal consider "teenager" as a legitimate category, whereas some, predominantly from villages in the Himalayas, do not recognize a transitioning stage between childhood and adulthood. ${ }^{10}$
Shanu, drawing from the work of Liechty, ${ }^{11}$ acknowledges how media outlets such as teen magazines are geared towards youth interests and build a linkage between consumers and producers at global and local scales; this further reinforces the ways in which Global North discourses dominate the construction of childhood in Nepal. ${ }^{12}$ Hart makes a similar critique of "adolescence," acknowledging its Western roots as an "artefact of modernity," and yet he still chooses this as the best term for his edited book, Years of Conflict: Adolescence, Political Violence, and Displacement. ${ }^{13}$ Hart's book squarely addresses a discourse of fear generated by some demographers, journalists, and analysts of the "youth bulge" whereby a society, usually in the Global South or Middle East, has a large and potentially explosive segment of youth in its population, relative to other age cohorts. The assumption that youth are prone to violence and that a large youth population is potentially dangerous is problematic and engages a politics that is not our focus here, but it does draw attention to youth as a risky population. Hart also traces the links between children, youth, adolescents, and education in the civil war in Nepal in considerable detail. ${ }^{14}$

Furthermore, we select "youth" for this paper, acknowledging its range of meanings across contexts. While social and economic status and language differences between youth from the city and those from the rural Himalayan communities cannot be overlooked, we avoid creating any notion of urban youth as more "developed" or modern than their rural counterparts who have long been assumed to be the target of national development projects, the "developees." 15 In the context of Nepal, Onta-Bhatta notes that since "childhood is created, experienced and re-created continually, writing about the social construction of childhood must encompass the shifting contexts, the various actors involved, and the intertwined social, cultural and political processes." 16

Bista, drawing from the work of Snellinger, acknowledges that "amongst ethnic communities whose economic livelihoods are agriculturally based, there is no dichotomization between children and adults in which, under particular circumstances, one ceases to be a child in order to become an adult."17 Carney and Madsen explore how socialization and acculturation in Nepal influence the ways in which migrant children from rural backgrounds negotiate new roles and subject positions and identity formations within educational contexts. ${ }^{18}$ Furthermore, Childs et al. observe that for child migration from the trans-Himalayan regions of Nepal, particularly the Mustang region, "within-district migration is much more common in Mustang due to the presence of more schools and religious institutions. Nevertheless, parents in all study areas who send their children 
to local boarding schools often envision this as a temporary solution, hoping to eventually secure a seat in a more prestigious school located outside the district or even outside Nepal ... Kathmandu is the most popular destination for external migrants, consistent with a high concentration of boarding schools and monasteries in the nation's capital."19 The youth respondents analyzed in this study illuminated how irregular and limited schooling prospects in their rural villages were a major factor in migration decisions. Of the twenty-two participants, thirteen never attended school during their time in the village. ${ }^{20}$

For students who had some schooling experiences in their villages, they were invariably put into lower grades than the ones from which they came once they arrived in Kathmandu, since they had no documentation to prove their school attendance, or citizenship documents to verify their age and identity. Many of the participants did not know their exact ages, since at the time of their birth, their age was not recorded. For example, as Poso states, "When I came to Kathmandu when I was six I was not given my birth certificate. I thought I was 16 but after returning to my village I found out that I was actually 18 " (Poso, age eighteen, Lower Dolpa). ${ }^{21}$ As a community development worker who was employed in the education sector in the Himalayan region noted, if numbers are used to depict age, they are counted as one year old when a child is born. Some villages consider the number thirteen as ominous, so it is skipped once a person reaches that age, and because of leap years in the Gregorian calendar overlapping with the Nepalese calendar system, sometimes a birthday is celebrated twice in one year. ${ }^{22}$

In addition, Clark-Kazak proposes that the concern with equating age only chronologically is that it strips age of social meanings and "overlooks the fact that chronological age is itself socially constructed-employed primarily as a 'marker' of human development in societies ordered by chronological time. In many other cultures, people do not know their chronological age." 23 To approach age in a more nuanced and contextualized manner, Clark-Kazak draws on the work of multiple scholars to construct the concept of "social-age."24 Social age ensures that "the social aspects and relationships related to age are adequately recognized and taken into account, we can employ the concept of 'social age' to indicate the socially constructed meanings applied to physical development and roles attributed to infants, children, young people, adults and elders, as well as their intra- and inter-generational relationships." ${ }^{25}$ In transitions from "childhood" to "adulthood," Gill Valentine notes that the transitions are "complex and fluid ... these transitions are bound up with wider structures such as ... the family." Such transitions become more fraught once youth leave the family for education in Kathmandu. ${ }^{26}$ If they were "sent" by their parents, concepts of children's "choice" and decision-making are difficult to discern until they navigate their return to see their families. Nanda Shrestha contends that parents tend to be the ones who send their children away to the cities to engage with bikas (Nepali for upward social mobility, or "development"). ${ }^{27}$ Yet, in the context of the Maoist rebels' project, there was legitimate fear of youth recruitment. As Lawoti and Pahari note, "As the armed conflict progressed and the need for recruits intensified the CPN-M [Communist Party of Nepal-Maoist] increasingly took to kidnapping entire classes or schools of children," predominantly in rural areas. ${ }^{28} \mathrm{In}$ foregrounding the words, encounters, and struggles of youth-especially the stories of Lhundup, one male youth who spoke at length about his emotional journeys alongside his travels to his village and back to Kathmandu-we aim to unsettle the more statecentric geopolitical research claims that poverty and war between a suppressive state and Maoist rebels simply caused youth relocation. ${ }^{29}$ While evidence shows that these factors did shape the context in which youth found themselves, youth are also protagonists and authors of their lives.

The particular youth represented in this study left their villages between the ages of four and ten. The meanings, age identities, and social expectations that accompany such youth vary from one society to another and over time, as the concept of "social age" above identifies..$^{30}$ Employing the concept of youth is a decision to use a term often ignored and under-theorized by migration scholars and policy-makers. ${ }^{31}$

The study comprised three focus groups and twentytwo semi-structured interviews with youth enrolled at a boarding school in Kathmandu and those who had recently graduated from it. Interviews ranged from one hour to four hours in length, were recorded with a digital device, and then were transcribed. Three focus groups with different configurations of young people were held: one included male ${ }^{32}$ youth from the Himalayan region; another included only female youth from Himalayan villages, and the last included male youth from Himalayan and non-Himalayan backgrounds. While excerpts from a range of interviews are featured in this article, we highlight the testimony of one male respondent in particular, "Lhundup," who spoke at length and in depth about his migrations to Kathmandu and back to his village on several occasions. The lead author of this article established strong rapport with many of the participants over four prior years of volunteer work at the school, and so was well known to and trusted by research participants (see table 1 for data on gender and geographical region of participants).

A sentiment shared by many participants who migrated to Kathmandu and resided in the boarding school for 
Table 1. Gender and geographical region of origin among participants

\begin{tabular}{|c|c|c|c|}
\hline \multirow[b]{2}{*}{ Region } & \multirow{2}{*}{$\begin{array}{c}\text { Number of } \\
\text { participant(s) }\end{array}$} & \multicolumn{2}{|c|}{ Gender } \\
\hline & & Male & Female \\
\hline Humla & 3 & 2 & 1 \\
\hline $\begin{array}{c}\text { Mustang (Upper } \\
\text { Region) }\end{array}$ & 2 & 1 & 1 \\
\hline $\begin{array}{c}\text { Mustang (Lower } \\
\text { Region) }\end{array}$ & 2 & 2 & - \\
\hline $\begin{array}{c}\text { Dolpa (Upper } \\
\text { Region) }\end{array}$ & 4 & 2 & 2 \\
\hline $\begin{array}{c}\text { Dolpa (Lower } \\
\text { Region) }\end{array}$ & 6 & 4 & 2 \\
\hline Mugu & 1 & 1 & - \\
\hline Manang & 1 & 1 & - \\
\hline Mixed backgrounds & 2 & Humla-Jumla & $\begin{array}{c}\text { Upper Dolpa- } \\
\text { Upper } \\
\text { Mustang }\end{array}$ \\
\hline
\end{tabular}

prolonged periods was the tension between living in Kathmandu and wanting to be back in their villages. ${ }^{33}$ At the beginning of one interview, Champo stated, "I do not want to start by sharing with the word firstly, and end with the word lastly, because my experience is more than just one beginning and one end ... Actually, sometimes there is an end before a beginning" (Champo, sixteen, Lower Dolpa). Champo's insight, similar to the rest of the participants' testimonies, reflects the fluidity of migration, villages, education, and family separation experiences. In order to gain access to and engage with youth testimonies, and to enter difficult discussions and sensitive conversations about civil war experiences, a comfortable and transparent space was created in which participants trusted they could share and also withdraw from the research at any time without repercussions. ${ }^{34}$ In this space, participants exchanged rich details about how they understood the reasons for their migration to Kathmandu, but also learned from it. For example Lhundup acknowledged,

This research project was definitely very useful. The process of working with you helped me to build my confidence with speaking and to draw attention to important details in my life. The most important thing this research has done is give me the ability to spread knowledge about Nepal and its Himalayan region's tradition, culture, past political conditions, living styles and religion. (Lhundup, nineteen, Upper Mustang)

Amrita noted,
We need more research like this that lets us express freely and feel comfortable doing so. Expressing our views is important but often when people ask us to express our views, the questions kind of already limits what you are going to say. (Amrita, sixteen, Lower Dolpa)

Holloway argues that children and youth voices "have something valuable to add to debates about their lives and we need to continue to insist on the importance of listening to them, even (perhaps especially) where their views challenge conventional academic and activist wisdom."35 Thus, the testimonies of youth help to bridge the realm of education and research by drawing upon different facets of children's lives to construct them as competent social actors within educational spaces, research spaces, and their own lived experiences. Our article expands the scholarship on children's geographies and in forced migration studies by focusing upon the lives of Himalayan youth migrating during a time of political unrest, but also by underscoring their agency, processes of identity construction and interpretation of their migration to the capital, separation from family, and education in Kathmandu.

The journeys that youth respondents undertook to get to Kathmandu span vast distances, often on foot, during a time when transportation was virtually non-existent and/ or affordable. As Stirr acknowledges, the far western parts of Nepal and the high mountains have long been neglected in infrastructural and economic development. ${ }^{36}$ This gap often resulted in long-term family separation. Shrestha, Carney and Madsen, and Basnett illuminate rural migration to cities like Kathmandu, while Childs et al. draw attention to particularities of migration from regions such as Mustang. ${ }^{77}$ Pertaining to migration in the Maoist context, Eck, Stirr, Kohrt et al., as well as Pettigrew and Adhikari illustrate the ways in which children were militarized during war in Nepal; they highlight the political ideologies and youth indoctrination around children's recruitment $3^{38}$ Youth interviewed in Kathmandu draw on their recollections and on stories they have been told by family members at the time before their initial separation, upon their return to visit their villages, from their perspectives. 39 We dwell less on the technical questions, and try to elicit how and why the decisions were made by the youth affected. We probe the outcomes of their migration, education, and separation, as well as the feelings that youth harbour, and the strategies they use to manage their complicated intercultural and geographical situations. Many now struggle with the loss of their mother tongue, and familial estrangement upon leaving school and returning to their home villages for visits or to live permanently. The article analyzes youths' meanings of their migration, in some cases provided to them by their 
parents more than a decade after reuniting with the youth, and traces the lived experience of separation and attendant feelings of rejection and abandonment. Some youth participants learned of their parents' fear that they might be recruited by the Maoists only years after they left home.

\section{On the Move}

From 1996 to 2006 and led by the Communist Party, the "People's War" was waged against the Nepali government, a royal parliamentary system. The uprising dragged on until 2006 and resulted in the deaths of thousands of Nepalese. Many youth were recruited as child soldiers by the Maoist rebels, especially in the rural trans-Himalayan region.40 Furthermore, "the year 1996 marked the launch of the 'People's War' against the authoritarian Nepali state. The rebel impetus behind the war was to fundamentally alter the 'historical relation of oppression' in the country."'11 According to Hachhethu, the political and ideological aims of the Maoist insurgency were to "overthrow the present polity based on multiparty parliamentary democracy and constitutional monarchy through armed revolution and its replacement with a new political system known as new people's democracy." 42

The remoteness of the Himalayan regions played a crucial role in the Maoist insurgency. It "facilitated the possibility of initiating and developing guerrilla wars in different parts of the country by taking peasant revolution as the backbone, by centralizing activities in the rural areas and by relying on and uniting with the poor peasants." 43 Far from being a separate issue, the "People's War" was fuelled largely by poverty, unemployment, underdevelopment, exclusion, corruption, and bad governance, which largely oppressed rural populations. 44

During the Maoist insurgency the Maoists recruited children and youth as combatants. Often there was a strong element of force; media reports stated that "the Maoists have taken hostages, tortured 'scores of people' and have recruited children as combatants." 45 Testimonies from formal child soldiers featured in the work of Kohrt et al. found that children who were recruited and attempted to flee "had the poorest outcomes possibly because their support system in the armed group transformed into a threat. Children reported being hunted down by the armed group to force them back into recruitment." 46 During the conflict in Nepal, Amnesty International had "called upon the warning parties to sign a Human Rights Accord to the National Human Rights Commissions (NHRC), a mandate to monitor human rights." 47 However, Crane suggests that media discourse was skewed in favour of the government. ${ }^{4}$ Lawoti and Pahari echo this in relation to international organizations, stating that communication sources were fragmented and created a bias, perpetuating a "good"/"bad" binary between the government and the Maoists. 49

The framing of recruitment as "forced" diminishes any agency that youth may have had in making a decision to join the rebel forces. Pettigrew and Adhikari trace the story of a former child soldier, Lek Bahadur, recruited by the Maoists during the civil war. Bahadur spent many hours in the Maoists' company and was impressed by their commitment to rural Nepal. The Maoists were the only party who discussed politics with Lek Bahadur without guns. He hoped that joining them might create a better life for his family and for him. Years of war created a political space in which Nepalis craved peace. "'Forgetting fear' both acknowledged an emotional state and reflected a choice ... people like Lek Bahadur had also made a choice. After years of conflict, people desperately wanted peace and by choosing to forget they actively engaged with the peace process." 50 Despite the lack of disclosure about Lek Badur's approximate age, Tiwari notes, "Close to 100,000 rural youths failing high school examination every year have neither a job nor a school to go where they could be kept busy. These unemployed youths, 15 to 18 years in age, are joining the ranks of armed guerrillas. The Maoists, however, have problems of providing arms to these willing recruits." ${ }^{51}$

The economic environment and lack of youth educational mobility extends part of the rationale for young people's involvement in radical movements. Zharkevich contends that the "Maoist movement in Nepal was self-consciously pedagogical, even if it was pursuing a goal opposite to that of formal schooling ... Arguably, in the context of war, and with a lack of opportunities for social mobility, a guerrilla movement can attract young people as an alternative provision for learning and a vehicle for social mobility." 52 Zharkevich highlights a dimension that Tiwari ignores, namely the complex matrix of conditions-economic, political, and educational-present in the rural Himalayan regions. Poverty, civil unrest, and scarce educational opportunities created conditions ripe for recruitment by the Maoist insurgency.

\section{Education or Separation? Youth Narrate Their Migration to and from Kathmandu}

In exploring the scholarship in children's geographies, and to a lesser extent within the forced migration literature, we use the youth narratives to analyze their role in the family and in relation to their return to their village as young adults. In doing so, we destabilize tacit assumptions that families simply "sent" their children away to escape danger and poverty. Just as subaltern subjects have no place from which to speak ${ }^{53}$ and refugees are "speechless emissaries" denied a subject position, 54 so too are children and youth often 
seen merely as wards of their parents, rather than actors in their own right.55 The subfield of children's geographies emphasizes place and exploring the everyday spaces of children and youth. ${ }^{56}$ According to geographer Cindi Katz, children's geographies "encompasses notions of children as active producers of space, as geographical subjects, and as environmental agents, at the same time as it recognizes children's limited mobility." 57 Following Katz's lead, one way to expand the boundaries of research on children's geographies is by placing more emphasis upon Global South contexts and differences in the construction of children and youth across time and space, in addition to increased interdisciplinary collaboration..$^{8}$ The social dimension of time is also important in this situation, since it helps to contextualize how participants articulate emotions and understandings of the Maoist uprising and its relation to youth migration journeys away from their remote villages.

The rebel uprising and arrival of the "People's War," sometimes called the Maoist Revolution, were relevant factors for youth migration away from rural villages. Eighteen of the twenty-two participants openly referred to either direct or indirect contact with the Maoists. Relations with the Maoists were complicated: on the one hand, recruitment was an issue and potential threat, but on the other, the offer of better educational opportunities if one joined the movement also mitigated any singular assessment of the rebels.

In a rural context, Zharkevich notes that "Maoist district committee members would come to the school, speak with the director, and then go and speak to students, encourage them to form a Maoist Student Union and organize informal classes for the study of Maoist theory," with the intention of later recruiting interested students. .99 The insurgency was seen as a potential option or pathway for youth (especially in rural regions) who were limited in school, work, and other life opportunities. Zharkevich adds that "carrying books in backpacks, compulsory independent study for several hours per day, and learning the basics of Marxist social theory and propagating it to Nepali villagers were common practices among Maoist youth."60 As Eck reiterates, "The recruitment strategy focused on voluntary membership consolidated through the use of intensive indoctrination. The group's ideology was presented in mass meetings-attendance at which was largely mandatory for local villagers-which promoted the group's ideological propaganda." ${ }^{1}$ Thus propaganda and indoctrination "fuelled the 'ideology-led" Maoist rebellion, positioning schools as key battlefields in a brutal and inhuman conflict." 62

Findings from the study complement the accounts above. When Ghephel was about seven years old, he recalls an encounter with one of his friends who was returning from grazing the cows and sheep; his friend was dressed up in
Maoist clothes. Ghephel asked him why he was wearing such an outfit, and his friend told him that the Maoist army had come to his school, given it to him, and promised a good education. Ghephel's fear that he could die in the conflict prevented him from even thinking about joining the Maoists, though he did contemplate the option of education it afforded (Ghephel, age sixteen, Lower Mustang). ${ }^{63}$ Ghephel's story reveals both the educational opportunities offered by the Maoists, and how education becomes, as Pajuil states, "a site where agency and structure are in constant interplay producing contestations and conflicts,"64 but also how the Maoists were able to use rural schools as a space for recruitment without the use of violence. Education was seen by the Maoists as a key ingredient in liberating youth in the rural Himalayan villages from the autocratic rule $^{65}$ and deprivation that preceded their arrival. ${ }^{66}$

On the other hand, experiences of violence and forced recruitment also increased the spontaneity of migration decisions to Kathmandu as respondents reported. Temba recounted,

We are three siblings, one elder brother who is already married and one younger sister who is younger than me ... The Maoists came and took one child from every home in our village, most of the times boys. My parents knew I had a good chance of being taken so they sent me to Kathmandu to study. But the Maoists still took my sister. She trained for a few years and then escaped with a boy who they also captured. She married him and they came to Kathmandu for hiding. She got married when she was fourteen and had one divorce already. But as I know I think she went back to the village because she could not find proper work in Kathmandu. She doesn't contact me much out of fear that someone may track her. (Temba, age seventeen, Humla ${ }^{67}$

Skamar recounted a similar story. When he was about four, the Maoists came to his village and his family's house. The Maoists set it on fire because his parents sent him out the back door out of fear that he might be recruited. Not having enough money for the entire family to migrate to Kathmandu, his parents first sent him to a distant relative and told him to stay there for safety and not to return. Later he travelled to Kathmandu. Skamar also mentioned his little brother, who was one year old at the time and did not leave the village; he recalls that during that period many young people migrated from his village and neighbouring regions (Skamar, age twenty, Lower Dolpa). ${ }^{68}$ Both Temba and Skamar narrate personal and familial fears of the Maoist insurgency-accentuating the importance of migration experiences as a child-specific phenomenon.

The testimony of Lhundup, a respondent in this study and graduate of the school, provided the most detailed 
and instructive responses. In an interview, he remembers his father telling him at the time (2001) that he was going to take him to Kathmandu where he would get the chance to study in a boarding school. Lhundup was excited to see Kathmandu, but did not fully realize that boarding school would result in long-term family separation. A major tension many participants experienced from staying in a boarding school related to cultural integration. Since all students came from different Himalayan regions, they spoke regionally specific dialects of Tibetan and/or Nepali. In learning a common language at the school, seventeen participants acknowledged that they have lost the ability to communicate in their village dialect. They can communicate only in the Nepalese and English mediums used in Kathmandu. Thus as time passed and Lhundup began to lose his village dialect, he felt that he was placed in school because his family no longer cared for him.

Nevertheless, Lhundup, who migrated to Kathmandu in 2003, had the rare opportunity over eleven years to visit his village twice in Upper Mustang. On his first return visit in 2007 , he was excited to visit his family. Upon arrival, however, he found that his father, an elder brother, and an elder sister were ambivalent towards him. A week later, his father told him that he had to return to Kathmandu since they (Lhundup's father, elder brother, and elder sister) were migrating to Lower Mustang for work. Lhundup felt agitated that he had spent so much time preparing to spend at least two months with his family, and they told him he had to leave after a week. After his return to Kathmandu his agitation turned into deep frustration, and eventually feelings of abandonment. In 2014, seven years later, after completing his secondary level of studies (class ten), Lhundup had the opportunity to visit his family once again. He was deeply conflicted about the visit and contemplated whether he really wanted to go. Eventually he did decide to visit. He recalled,

When I was returning I often had to use a tractor. Just think of how physically hard it is, with the dust and wind, for about six hours at a time for two days without sitting. In these moments I was really regretting going back and vowed that I never will. I was with some other villagers on the tractor, and when I told them my emotions, they said that tourists were coming to our village by spending lots of money, so I should be happy to have the opportunity to live there. But I was thinking, even I would like to go to other countries to visit, same like the tourist, but there is a difference with visiting a place and wanting to live there permanently. However, when I saw the [very poor] condition of my village and my family, my thoughts completely changed and it made me want to come back again. That day I came to a realization ... Whatever the situation in life, good or bad, events will happen that you cannot control. Whatever the outcome, it helps you to learn. I don't know what I will do in my future but I will try my best to keep and expand my relations with my village and family. (Lhundup, age nineteen, Upper Mustang) ${ }^{69}$

Lhundup's self-reflection and dialogue with his estranged family changed his feelings of abandonment to feelings of acceptance. Specifically, Lhundup came to terms with his family's apparent indifference toward him during his prior visit in 2007. Not until his visit in 2014 did Lhundup come to understand that his family wanted him to be safe from the Maoist insurgency and how the threat of rebel recruitment affected his life course. During his trip home in 2014, his father began to cry when Lhundup told him that putting the boy in a boarding school in 2001 had made him feel rejected from the family. His father told him then that the Maoists insisted that one child join the Maoist movement from each household, so out of fear that Lhundup would be recruited, his father decided that schooling in Kathmandu, far away from Upper Mustang, was the safest option.

His father had also made the difficult decision to send Lhundup's two younger sisters and two elder brothers to a school in India. Lhundup's youngest brother was also sent to a school in Lower Mustang to avoid recruitment. Only Lhundup's eldest sister and brother remained in Mustang, as they were much older than the other siblings and therefore were not at risk of being recruited by the Maoists. As Lhundup recalled, his father told him that each experience of placing his children in various boarding schools was hard and emotional. He apologized to Lhundup for the lack of emotions expressed when his son visited in 2007, and acknowledged that despite the official end of the Maoist revolution in 2006, there were still some small-scale Maoist activities throughout the Himalayas. His father sent him back to school in Kathmandu with the intention of protecting him, but without Lhundup understanding this. Despite his efforts, Lhundup still feels somewhat like an outsider in his home village because he cannot fluently speak his mother tongue, but he has been trying to relearn his village dialect. Furthermore, Lhundup is creating new spaces for cultural exchange by working with an international NGO to facilitate communication and bridging programs between villages in Mustang (and neighbouring Himalayan villages) with Himalayan youth living in Kathmandu and Pokhara.

Lhundup's efforts to facilitate community development projects predominantly in education and communication illustrate Ager and Strang's concepts of social bonds and social bridges..$^{70}$ According to the authors, social bonds occur between and among members of families and coethnic, co-national, co-religious groups. Those who belong 
to an ethnic enclave, for example, and share cultural practices and language would maintain social bonds. ${ }^{71}$ Those from Mustang with whom Lhundup works in Kathmandu and Pokhara share social bonds. Social bridges, in contrast, connect one distinct cultural or linguistic community with another, or with a host/dominant community. This represents a higher degree of social integration, which can facilitate wider community participation by all members and potentially better educational, employment, and economic opportunities..$^{2}$

Lhundup intends to use his networks and knowledge from boarding school in the capital-to create social bridges among different Himalayan groups, but also between these villages and the international non-governmental organizations working out of Kathmandu. For example, Lhundup is assisting with a pilot program in which Himalayan students use drama and digital media at non-Himalayan schools to address migration, gender discrimination, the acquisition of citizenship, and construction of identity. The program will run in partnership with local multiple NGOs and Tribuhvan University (the national university of Nepal). From Shrestha's perspective, the promise of bikas ${ }^{73}$ is both realized and unsettled by the experiences of the respondents in this study who are now much better educated than their other family members, but also alienated from them through years of separation 74

Almost all respondents interviewed experienced cultural dislocation from their home villages upon return, especially due to the loss of their mother tongue. Youth balance their feelings of abandonment and rejection with knowledge of their parents' fears about their recruitment and safety. Whether most youth will return to their Himalayan villages upon graduation remains an open question, despite relative peace in Nepal but also in the context of the recent earthquake. 75

\section{Conclusion}

The meanings that Himalayan youth attach to their migration to the capital, separation from family, and education in Kathmandu are multiple and contested over time and across their own youthful lifespans. While youth recollect and understand that their families wanted to protect them from rebel recruitment during the period of the "People's War," they also experienced strong feelings of rejection, disappointment, and abandonment in some cases. The findings presented here have outlined some of the negative social outcomes and emotional turmoil recounted by youth affected by their relocation in the name of their "protection."

Youth should not simply be second-guessed or spoken for when they can be consulted or engaged in dialogue about major decisions affecting them. While parents may feel it is their role to shelter their dependents by taking action to protect them, academics have no reason to "voice over" youth accounts of their situation or assume that abrupt, if intentional relocation is different from displacement generated by civil war. Youth protagonists produce spaces for different kinds of knowledge that can complement more conventional research on conflict, displacement, and migration created at the scale of the state or the global economy.

Adrian A. Khan is a PhD student in geography at the University of Toronto, where he is also affiliated with the Centre for Diaspora and Transnational Studies and the Centre for Asian Studies. He completed his MA in Development Studies at York University, based on research with youth from the trans-Himalayan region of Nepal. He has spent many years as a volunteer and teacher with youth at schools in the Kathmandu Valley. The author may be contacted at adriankhan314@gmail.com.

Jennifer Hyndman is professor in social science and geography at York University, Toronto, where she is also affiliated with the Centre for Refugee Studies. Her research focuses on the geopolitics of forced migration in and from conflict zones and refugee camps to resettlement policy and outcomes in North America. She is the author of Dual Disasters: Humanitarian Aid after the 2004 Tsunami (2011), Managing Displacement: Refugees and the Politics of Humanitarianism (2000), and co-editor, Sites of Violence: Gender and Conflict Zones (2004). The author may be contacted at jhyndman@yorku.ca.

\section{Notes}

1 The authors would like to thank anonymous reviewers for their constructive comments and suggestions, as well as Terence Rudolph for his insights and assistance on the article.

2 Wangdak, personal interview, 2014.

3 Y. Basnett, "From Politicization of Grievances to Political Violence: An Analysis of the Maoist Movement in Nepal," London School of Economics (LSE) 78, no. 78 (2009): 1-33.

4 K.C. Tiwari, "Maoist Insurgency in Nepal: Internal Dimensions," South Asia Analysis Group 187, no. 1 (2001): 1-8.

5 J. Pettigrew and K. Adhikari, "Fear and Everyday Life in Rural Nepal," Dialectical Anthropology 33, nos. 3-4 (2009): 421.

6 B.A. Kohrt, J.D. Jordans, E. Perera, R. Karki, S. Koirala, and N. Upadhaya, "Social Ecology of Child Soldiers: Child, Family, and Community Determinants of Mental Health, Psychosocial Well-being, and Reintegration in Nepal," Transcultural Psychiatry 47, no. 5 (2010): 743. 
7 See M. Lawoti and A.K. Pahari, The Maoist Insurgency in Nepal: Revolution in the Twenty-First Century (New York: Routledge, 2010).

8 D. Haraway, "Situated Knowledges," in Simians, Cyborgs, and Women: The Reinvention of Nature, 183-203 (New York: Routledge, 1991).

9 See, for example, J. Hart, "Introduction," in Years of Conflict: Adolescence, Political Violence and Displacement, ed. J. Hart, 1-22 (New York: Berghahn Books, 2008); D. Chatty, "Introduction: Deterritorialized Youth: Sahrawi and Afghan Refugees at the Margins of the Middle East," in Deterritorialized Youth: Sahrawi and Afghan Refugees at the Margins of the Middle East, ed. D. Chatty, 1-34 (New York: Berghahn Books, 2010); C.R. Clark-Kazak, Recounting Migration: Political Narratives of Congolese Young People in Uganda (Montreal and Kingston: McGillQueen's University Press, 2011).

10 N. Ansell, Children, Youth, and Development (New York: Routledge, 2005), 85.

11 See M. Liechty, Out Here in Kathmandu: Modernity on the Global Periphery (Kathmandu: Martin Chautari, 2010).

12 B.M. Shahu, review of Out Here in Kathmandu: Modernity on the Global Periphery, by Mark Lichechty, Dhaulagiri Journal of Sociology and Anthropology 6 (2012): 143-52.

13 Hart, "Introduction," 4.

14 J. Hart, "Conflict in Nepal and Its Impact on Children," Refugee Studies Centre, 2001, http://www.rsc.ox.ac.uk/ files/publications/other/dp-children-armed-conflictnepal.pdf.

15 See, for example, T. Jakimow, "Spoiling the Situation: Reflections on the Development and Research Field," Development in Practice 23, no. 1 (2013): 21-32; Stacy Leigh Pigg, "Inventing Social Categories through Place: Social Representations and Development in Nepal," Comparative Studies in Society and History 34, no. 3 (1992): 491-513.

16 L. Onta-Bhatta, "Childhood Constructed, Childhood Lived: Law and Social History in Nepal," Studies in Nepali History and Society 6, no. 2 (2001): 232.

17 A. Snellinger, "Shaping a Livable Present and Future: A Review of Youth Studies in Nepal," European Bulletin of Himalayan Research (EBHR) 42 (2O13): 75.

18 S. Carney and U.A. Madsen, "A Place of One's Own: Schooling and the Formation of Identities in Modern Nepal," in Nation-Building, Identity and Citizenship Education (Dordrecht: Springer, 2009), 171.

19 G. Childs, S. Craig, C.M. Beall, and B. Basnyat, "Depopulating the Himalayan Highlands: Education and Outmigration from Ethnically Tibetan Communities of Nepa," Mountain Research and Development 34, no. 2 (2014): 85-94.

20 One student attended school for a month before deciding he did not like it and left. One student was expelled in preschool for not attending classes regularly. Three students attended once to twice a week until they migrated to Kathmandu. Four students did have "regular" schooling experiences (attended a minimum of four of six school days per week). Of those four students, the first attended two years of primary schooling (class one and class two) before he migrated from Lower Mustang; the second student from Upper Dolpa attended a boarding school in the headquarters of Dolpa (Dunai) for three years (primary class one to three); the third attended government-funded school for four years (primary class one to four) before she migrated from Upper Mustang; and the fourth student attended school for five years (primary class one to five) before he migrated from Lower Mugu.

21 Poso, personal interview, 2014.

22 Personal communication, 5 June 2014.

23 C. Clark-Kazak, "Towards a Working Definition and Application of Social Age in International Development Studies," Journal of Development Studies 45, no. 8 (2009): 1-18.

24 Ibid.; see G. Elder, "Age Differentiation and the Life Course," Annual Review of Sociology 1 (1975): 165-90; H. Wulff, "Introducing Youth Culture in Its Own Right: The State of the Art and New Possibilities," in Youth Cultures: A Cross-cultural Perspective, ed. V. Amit-Talia and $\mathrm{H}$. Wulff, 1-16 (London: Routledge, 1995); A. James, C. Jenks, and A. Prout, Theorizing Childhood (Cambridge: Polity, 1998); N. Lesko, Act Your Age! A Cultural Construction of Adolescence (London: Routledge, 2001).

25 Ibid.

26 G. Valentine, "Boundary Crossings: Transitions from Childhood to Adulthood," Children's Geographies 1, no. 1 (2003): 37-52.

27 N. Shrestha, "Becoming a Development Category," in Development: A Cultural Study Reader, ed. Susanne Schech and Jane Haggis, 103-14 (Oxford: Blackwell Publishers, 1995).

28 Lawoti and Pahari, "Maoist Insurgency in Nepal."

29 I. Zharkevich, "Learning in a Guerrilla Community of Practice: Literacy Practice, Situated Learning, and Youth in Nepal's Maoist Movement (1996-2006)," Digital Himalaya 42, no. 1 (2013): 104-32.

30 Clark-Kazak, "Towards a Working Definition and Application of Social Age."

31 O. Bakewell, "Research beyond the Categories: The Importance of Policy Irrelevant Research into Forced Migration," Journal of Refugee Studies 21, no. 4 (2008): 432-53.

32 A shortcoming of using "youth" as an organizing concept is that the English language does not have genderappropriate adjectives to qualify youth, so one must use biological designations of "male" and "female" instead.

33 J. Hyndman, "The Field as Here and Now, Not There and Then," Geographical Review 91, nos. 1-2 (2001): 262-72.

34 Ibid.

35 L.S. Holloway, "Changing Children's Geographies," Children's Geographies 12, no. 4 (2014): 382. 
36 A. Stirr, "Changing the Sound of Nationalism in Nepal: Deudā Songs and the Far Western Region," South Asian Popular Culture 10, no. 3 (2012): 274.

37 See Shrestha, "Becoming a Development Category"; Carney and Madsen, "Place of One's Own"; Basnett, "From Politicization of Grievances to Political Violence"; Childs et al., "Depopulating the Himalayan Highlands."

38 K. Eck, "Coercion in Rebel Recruitment," Security Studies 23 (2014): 364-98; Stirr, "Changing the Sound of Nationalism in Nepal”; Kohrt et al., "Social Ecology of Child Soldiers"; Pettigrew and Adhikari, "Fear and Everyday Life in Rural Nepal."

39 Methodologically, neither the youth nor their families could be interviewed at or near the time this decision to migrate was made, since political tensions in relation the drafting of Nepal's constitution during the time of research restricted travel to trans-Himalayan regions.

40 Lawoti and Pahari, "Maoist Insurgency in Nepal," 3.

41 Basnett, "From Politicization of Grievances," 4.

42 K. Hachhethu, "Maoist Insurgency in Nepal: An Overview," in The Naxal Challenge: Causes, Linkages and Policy Option, ed. P.V. Ramana, 136-52 (New Delhi: Darling Kindersley (India) Pearson Education, 2008).

43 Ibid., 138.

44 Ibid., 139.

45 S.D. Crane, The Maoist Insurgency in Nepal: 1996-2001 (Carlisle: U.S. Army war College Strategic Studies Institute, 2002), 1-29.

46 Kohrt et al., "Social Ecology of Child Soldiers," 743.

47 Lawoti and Pahari, "Maoist Insurgency in Nepal," 230.

48 Crane, Maoist Insurgency in Nepal.

49 Lawoti, and Pahari, "Maoist Insurgency in Nepal," 218.

50 Pettigrew and Adhikari, "Fear and Everyday Life in Rural Nepal," 421.

51 Tiwari, "Maoist Insurgency in Nepal," 4.

52 Zharkevich, "Learning in a Guerrilla Community of Practice," 104-32.

53 G.C. Spivak, "Can the Subaltern Speak?," in Marxism and the Interpretation of Culture, ed. Nelson and Grossberg, 66-111 (Urbana: University of Illinois Press, 1988).

54 L. Malkki, "Speechless Emissaries: Refugees, Humanitarianism, and Dehistoricization," Cultural Anthropology 11, no. 3 (1996): 377-404.

55 J. Boyden, "Preface."

56 See, for example, S.L. Holloway and G. Valentine, "Children's Geographies and the New Social Studies of Childhood," in Children's Geographies: Playing, Living, Learning, ed. S.L. Holloway and G. Valentine, 1-26 (New York: Routledge, 2000); S.L. Holloway and H. Pimlott-Wilson, "Geographies of Children, Youth and Families: Defining
Achievements, Debating the Agenda," in Geographies of Children Youth and Families: An International Perspective, ed. L. Holt, 9-24 (Florence, ky: Routledge, 2011); N. Maine, "Refugee Youth Brokers Guiding Resettlement in Canada (MA thesis, York University, 2015).

57 C. Katz, "Children," in Dictionary of Human Geography, 5th ed., ed. D. Gregory, R. Johnston, G. Pratt, M. Watts, and S. Whatmore (Hoboken, NJ: Wiley-Blackwell, 2009), 80-1.

58 Holloway, “Changing Children's Geographies," 386.

59 Zharkevich, "Learning in a Guerrilla Community," 114.

60 Ibid., 106.

61 See J. Becker, "Child Recruitment in Burma, Sri Lanka, and Nepal," in Child Soldiers in the Age of Fractured States, ed. Scott Gates and Simon Reich (Pittsburgh: University of Pittsburgh Press, 2009), 64; K. Eck, "Recruiting Rebels: Indoctrination and Political Education in Nepal," in The Maoist Insurgency in Nepal: Revolution in the 21st Century, ed. Mahendra Lawoti and Anup Pahari, 33-52 (London: Routledge, 2010).

62 Eck, "Coercion in Rebel Recruitment," 386.

63 Ghephel, personal interview, 2014.

64 M.N. Parajuli, "Schooling: The Way People See It," Journal of Education and Research 1 (2008): 31-40.

65 For more details on different Maoist political shifts within the civil war, see A. Adhikari, B. Gautam, S. Pudasaini, and B. Sharma, Impunity and Political Accountability in Nepal (Kathmandu: Asian Foundation, 2014). 1-120.

66 Hart, "Conflict in Nepal and Its Impact on Children."

67 Temba, personal interview, 2014.

68 Skamar, personal Interview, 2014.

69 Lhundup, personal Interview, 2014.

70 A. Ager and A. Strang, "Understanding Integration: A Conceptual Framework," Journal of Refugee Studies 21, no. 2 (2008): 166-91.

71 Ibid., 178.

72 Ibid.

73 In relation to (social) mobility, development, agency, and gender, see J. Brunson, "Scooty Girls': Mobility and Intimacy at the Margins of Kathmandu," Ethnos 79, no. 5 (2014): 610-29.

74 Shrestha, "Becoming a Development Category."

75 The devastating earthquake in April 2015 has shaped some of the youths' aspirations to return to their villages, since the homes they were residing in, in Kathmandu, were severely damaged. If housing alternatives cannot be arranged in the city, some youth may return to their rural villages. The first author returned to Kathmandu in June to July 2015; this observation is based on several personal communications. 